\title{
Silver Nanoparticles; A New Hope In Cancer Therapy?
}

\author{
Sukriye Yesilot, Cigdem Aydin \\ Mehmet Akif Ersoy University, Bucak School of Health, Burdur, Turkey
}

\begin{abstract}
Nowadays, with the rapid developments in nanotechnology, there has been a significant increase in the usage of nanoparticles within the biomedical field. Nanoparticles are known as particles ranging in size between 1 and $100 \mathrm{~nm}$. Especially, silver nanoparticles (AgNPs) have been extensively carried out biomedical areas because of their physicochemical, and biological therapeutic properties. Recent studies have shown that there are anti-fungal, anti-viral, anti-inflammatory, anti-angiogenic biological activities, especially anti-bacterial and anti-cancer features of silver nanoparticles. Also, the appropriate knowledge of these characteristics is crucial since this knowledge enhances their potential usage in many areas while decreasing their possible dangers for human and environment. Recent researches demonstrate that multifunctional cytotoxic biological activities of biosynthesized silver nanoparticles can be used as an anti-cancer agent. In this work, it is aimed to give a literature review of the studies on silver nanoparticles, synthesis techniques and their possible usages especially in cancer therapy.
\end{abstract}

Key Words: Silver nanoparticles, Anticancer, Nanotechnology

\section{Introduction}

Nanotechnology, developing area, has several interdisciplinary fields, like electronics, medicine and biomaterials. Nanomedicine, in the long run aims to improve the health care system by dealing with mortal diseases more efficiently. Nanotechnology, ranging in size from $10 \mathrm{~nm}$ to $1000 \mathrm{~nm}$, involves the design, synthesis and manipulation of structures in particles.

For creation of nanoscale value properties, microbial origins and plants are used because of their physical and chemical properties. Currently, nanobiotechnology is seen as means of producing the synthesis of nanoparticles an economical option for chemical and physical methods $(1,2)$. Nanoparticles have unique chemical, physical and biological properties, and they are used in a lot of fields like therapeutics, cosmetics and drug delivery (3).

Nanoparticles present a new perspective for detection, protection and treatment of tumors. Because of, the speed improvement of varied diagnostic devices and therapeutic strategies, the mortality of cancer, known as one of the most deadly disease, has been significantly inhibited. Unfortunately, there is no method to select and bind cancer cells in order to prevent toxicity and side effects in all current cancer treatments. To overcome this situation, the synthesis of nanoparticles emerges as a new additive. To over come this problem, nanoparticles synthesis are emerged as a new contribution (4). Also, nanoparticles have been currently widely used in biomedical area due to its physicochemical properties and they are expected hopefully to reform the cancer diagnosis and therapy (5).

Nowadays, physical, chemical and biological techniques are used in the preparation nanoparticles. Although physical methods are used initially in the synthesis of nanoparticles, low yield is the biggest disadvantage. Chemical methods use various chemicals to synthesis of silver nanoparticles and to reduce metallic ions. But, chemical methods include some drawbacks related to the use of toxic chemicals and hazardous production according to the products. (6). Among these methods, biological method is a good way to fabricate nanoparticles. And also, this method is less toxic and eco friendly. Coating agents are used in the synthesis of nanoparticles. Nanoparticles absorb these coating agents which are usually organic molecules, and used to help stabilization of nanoparticles. From a medical point of view, biosynthesis of nanoparticles has been shown to greatly increase their clinical application.

The natural resources for green biosynthesis of nanoparticles are plants, bacteria, yeast, algae, fungi and viruses (7). Although creating a large platform of green biosynthesis in production of nanoparticles, the most commonly bacterial 


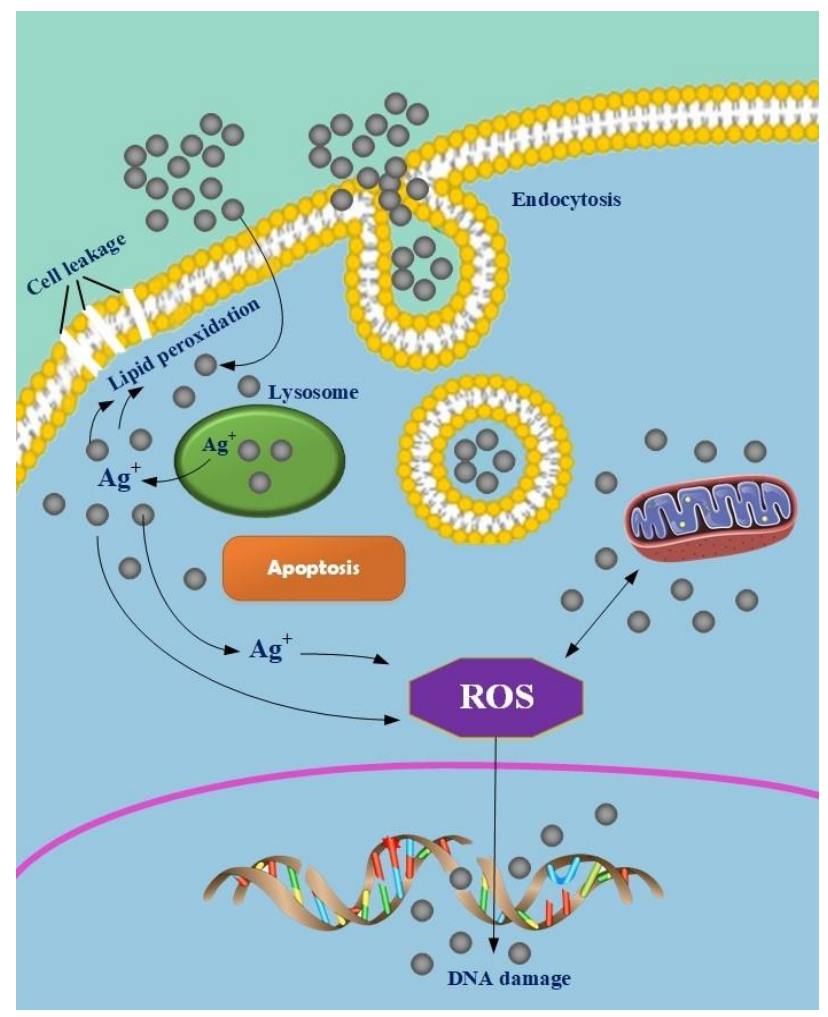

Fig.1. Schematic representation of the mechanism of anticancer effect of silver nanoparticles

synthesis is preferred, because they are easy to process and genetic manipulation is also possible (8-10). Interestingly, recent studies demonstrated that using medical plants for production of nanoparticles could be cost effective and ecofriendly. For this reason, the green biosynthesis has become the most commonly used method for investigating therapeutic agents for cancer treatment (4).

Due to advances in nanotechnology, new therapeutic approaches have been developed for the use of nanoparticles in medicine. Among the commonly used nanoparticles, AgNPs have an impressive role due to their unique physical and chemical features. In addition, AgNPs have a stronger effect than the silver ions as disclosed in some research. Silver is a noble metal extensively used to make coin and jewelry over 200 years. Also, this element is resistant to bacteria and is a potential anti-bacterial agent with low toxicity (11). In ancient times, silver was used to protect water and its believed to be source the healing because of anti-disease properties by Hippocrates. Then, silver components were used in medical applications. These compounds have also been widely used against wound infections in World War I instead of antibiotics. Silver has been made to have extraordinarily novel morphological and characteristic properties with engineering and the development of new technologies. Due to nanotechnology, silver ions are processed and transformed into ultra-small particles measured in nanometers (nm) (12-16). Upon reaching nanoscale, silver particles have physicochemical properties and create exceptional biological activities. This distinctiveness of silver nanoparticles widen their application in antibacterial, anti-fungal, anti-viral, anti-inflammatory, anti-angiogenic and anti-cancer therapy. AgNPs are widely used in production of cosmetics, detergents and hygienic goods. Recent studies have indicated that AgNPs do not harm humans and kill viruses, bacteria and other eukaryotic microorganisms without any adverse effects in diluted concentrations. (17).

Many studies have shown that silver nanoparticles have made their way into therapeutic applications in cancer as anti-cancer agents (18). Several in vitro studies have indicated that silver nanoparticles can enter cells by endocytosis and their localization inside the cell can be determined as the perinuclear space of cytoplasm and endolysosomal compartment $(19,20)$. Besides, silver nanoparticles can enter the mitochondria and produce reactive oxygen species (ROS) by affecting the respiration of cells. In summary, the mechanisms of AgNPs as toxic can lead to DNA damage, oxidative stress, induction of apoptosis, and mitochondrial damage to cancer cells. (21-26). The mechanism of action of silver nanoparticles on cancer cells is schematized in (figure 1). Furthermore, there are studies that AgNPs affect the function of the vascular endothelial growth factor (VEGF). It is also known as vascular permeability factor and plays a major role in the angiogenesis within tumors (27). These results support AgNPs have anti-cancer properties that can be used as an alternative for cancer therapy and angiogenesis inhibitor therapy (28).

Theranostic applications of green-synthesized nanoparticles were investigated for biologically compatible and potential approaches in biomedical field (antimicrobial, anti-inflammatory, antinociceptive, anticancer and enzyme inhibition activities). Theranostic is defined a combination of diagnostics and therapy. The bio-synthesized AgNPs could be used in theranostic applications including anti-cancer therapeutic agent, drug delivery and bioimaging vehicle (29). Green AgNPs can be used as beneficial theranostic agents for further discovery of various biomedical applications (30-32). AgNPs, which were biosynthesized with various applications, were tested in different cancer cell lines. Table 1 summarizes the recent studies 
Table 1. Application of AgNPs used in different cancer cell lines

\begin{tabular}{|c|c|c|c|c|c|}
\hline $\begin{array}{l}\text { Green synthesis } \\
\text { Ganoderma neo-japonicum } \\
\text { Imazeki }\end{array}$ & Breast Cancer & $\begin{array}{l}\text { MDAMB- } \\
231\end{array}$ & $\mathrm{IC}_{50}: 8,7 \mu \mathrm{g} / \mathrm{mL}$ & $\begin{array}{l}\text { Dose-dependent inhibition of } \\
\text { cell growth }\end{array}$ & 33 \\
\hline $\begin{array}{l}\text { Green synthesis } \\
\text { Sucrose }\end{array}$ & $\begin{array}{l}\text { Malignant skin } \\
\text { melanoma and } \\
\text { squamous cell } \\
\text { lung carcinoma }\end{array}$ & $\begin{array}{l}\text { HT144 } \\
\text { and } \\
\text { H157 }\end{array}$ & $\mathrm{ID}_{50}: 3.6 \mu \mathrm{M}$ & $\begin{array}{l}\text { Remarkable antitumor potency } \\
\text { compared to the clinically } \\
\text { used reference compounds } \\
\text { vincristine and methotrexate }\end{array}$ & 34 \\
\hline $\begin{array}{l}\text { Chemical synthesis } \\
\text { Polyvinylpyrrolidone(PVP) }\end{array}$ & $\begin{array}{l}\text { Acute myeloid } \\
\text { leukemia }\end{array}$ & AML & $0-10 \mathrm{mg} / \mathrm{mL}$ & $\begin{array}{l}\text { AgNPs has been observed to } \\
\text { have an inhibitory effect with } \\
\text { low IC }{ }_{50}(0.90-3.43 \mathrm{mg} / \mathrm{mL}) \\
\text { in six AML cells. }\end{array}$ & 35 \\
\hline $\begin{array}{l}\text { Green synthesis } \\
\text { Taraxacum officinale }\end{array}$ & $\begin{array}{l}\text { Liver } \\
\text { hepatocellular } \\
\text { carcinoma }\end{array}$ & HepG2 & $\begin{array}{l}10 \text { to } 200 \mu \mathrm{g} / \mathrm{mL} \text { dose- } \\
\text { dependent }\end{array}$ & $\begin{array}{l}\text { A high cytotoxic effect was } \\
\text { observed in HepG } 2\end{array}$ & 36 \\
\hline $\begin{array}{l}\text { Green synthesis } \\
\text { Commelina nudiflora L. }\end{array}$ & Colon Cancer & НCT-116 & $\mathrm{IC}_{50}: 100 \mu \mathrm{g} / \mathrm{mL}$ & $\begin{array}{l}\text { Diminished cell viability and } \\
\text { increased cytotoxic effect in } \\
\text { HCT-116 }\end{array}$ & 37 \\
\hline $\begin{array}{l}\text { Chemical biosynthesis } \\
\text { Phycocyanin }\end{array}$ & $\begin{array}{l}\text { Human breast } \\
\text { adenocarcinoma }\end{array}$ & MCF-7 & $\begin{array}{l}\mathrm{IC}_{50}: 27.79 \pm 2.3 \mu \mathrm{g} / \\
\mathrm{mL}\end{array}$ & $\begin{array}{l}\text { Inhibition of tumor growth in } \\
\text { Ehrlich-ascites carcinoma- } \\
\text { bearing mice }\end{array}$ & 38 \\
\hline $\begin{array}{l}\text { Green synthesis } \\
\text { Melia dubia }\end{array}$ & $\begin{array}{l}\text { Human breast } \\
\text { cancer }\end{array}$ & MCF-7 & $\mathrm{IC}_{50}: 31.2 \mu \mathrm{l} / \mathrm{ml}$ & $\begin{array}{l}\text { AgNps showed remarkable } \\
\text { cytotoxicity activity with } \\
\text { evidence of high therapeutic } \\
\text { index value against MCF-7 }\end{array}$ & 39 \\
\hline $\begin{array}{l}\text { Mycosynthesis } \\
\text { Inonotus obliquus }\end{array}$ & $\begin{array}{l}\text { Human lung } \\
\text { cancer } \\
\text { human breast } \\
\text { cancer }\end{array}$ & $\begin{array}{l}\text { A549 } \\
\text { and } \\
\text { MCF7 }\end{array}$ & $\mathrm{IC}_{50}: 100 \mu \mathrm{l} / \mathrm{ml}$ & $\begin{array}{l}\text { Significant cytotoxic effect in } \\
\text { A549 and MCF-7 cell lines }\end{array}$ & 40 \\
\hline $\begin{array}{l}\text { Green synthesis } \\
\text { Erythrina indica lam }\end{array}$ & $\begin{array}{l}\text { Breast and lung } \\
\text { cancer }\end{array}$ & $\begin{array}{l}\text { MCF-7 } \\
\text { and } \\
\text { HEP G2 }\end{array}$ & $\begin{array}{l}23.89 \pm 0.39 \mu \mathrm{l} / \mathrm{ml} \text { for } \\
\text { MCF- } 7 \\
13.86 \pm 0.95 \mu \mathrm{l} / \mathrm{ml} \text { for } \\
\text { HEP G2 }\end{array}$ & $\begin{array}{l}\text { Significant cytotoxic effect in } \\
\text { MCF- } 7 \text { and HEP G2 cell lines }\end{array}$ & 41 \\
\hline $\begin{array}{l}\text { Green Synthesis } \\
\text { Acalypha indica Linn }\end{array}$ & $\begin{array}{l}\text { Human breast } \\
\text { cancer }\end{array}$ & $\begin{array}{l}\text { MDA- } \\
\text { MB-231 }\end{array}$ & $\mathrm{IC}_{50}: 100 \mu \mathrm{g} / \mathrm{ml}$ & $\begin{array}{l}\text { Important cytotoxic effects and } \\
\text { apoptotic properties }\end{array}$ & 42 \\
\hline $\begin{array}{l}\text { Green Synthesis } \\
\text { Dendrophthoe } \\
\text { falcata (L.f) Ettingsh }\end{array}$ & $\begin{array}{l}\text { Human breast } \\
\text { cancer }\end{array}$ & MCF-7 & $\mathrm{IC}_{50}: 5 \mu \mathrm{g} / \mathrm{mL}$ & $\begin{array}{l}\text { Significant cytotoxic effect in } \\
\text { MCF-7 cell line }\end{array}$ & 43 \\
\hline $\begin{array}{l}\text { Green Synthesis } \\
\text { Datura inoxia }\end{array}$ & $\begin{array}{l}\text { Human breast } \\
\text { cancer }\end{array}$ & MCF7 & $\mathrm{IC}_{50}: 20 \mu \mathrm{g} / \mathrm{ml}$ & $\begin{array}{l}\text { Antiproliferative effect, cell } \\
\text { cycle arrest, decreased DNA } \\
\text { synthesis and apoptosis }\end{array}$ & 44 \\
\hline $\begin{array}{l}\text { Green Synthesis } \\
\text { Piper longum }\end{array}$ & $\begin{array}{l}\text { Epidermoid } \\
\text { Larynx } \\
\text { Carcinoma }\end{array}$ & HEp-2 & $\mathrm{IC}_{50}: 500 \mathrm{lg} / \mathrm{mL}$ & $\begin{array}{l}\text { Exhibit a prominent cytotoxic } \\
\text { effect }(94.02 \%) \text { on HEp- } 2 \text { cell } \\
\text { lines }\end{array}$ & 45 \\
\hline $\begin{array}{l}\text { Green Synthesis } \\
\text { Sargassum vulgare }\end{array}$ & $\begin{array}{l}\text { Human } \\
\text { myeloblastic } \\
\text { leukemic and } \\
\text { cervical cancer }\end{array}$ & $\begin{array}{l}\text { HL60 } \\
\text { and } \\
\text { HeLa }\end{array}$ & EC50: $93.57 \mu \mathrm{g} / \mathrm{ml}$ & $\begin{array}{l}\text { Preventing the irradiation- } \\
\text { related carcinogenesis with } \\
\text { DNA damage and apoptosis }\end{array}$ & 46 \\
\hline $\begin{array}{l}\text { Mycosynthesis } \\
\text { Saccharomyces boulardii }\end{array}$ & $\begin{array}{l}\text { Human breast } \\
\text { cancer }\end{array}$ & MCF-7 & $(10-100 \mu \mathrm{g} / \mathrm{mL})$ & $\begin{array}{l}\text { Very low concentration of } \\
\text { AgNps showed very high } \\
\text { activity in MCF-7 cells } \\
\text { compared to silver ions }\end{array}$ & 47 \\
\hline $\begin{array}{l}\text { Green Synthesis } \\
\text { Pimpinella anisum seeds }\end{array}$ & $\begin{array}{l}\text { Human neonatal } \\
\text { skin stromal and } \\
\text { colon cancer }\end{array}$ & $\begin{array}{l}\text { hSSCs } \\
\text { and } \\
\text { HT115 }\end{array}$ & $\begin{array}{l}>10 \mu \mathrm{g} \\
(20,30,40,50 \mu \mathrm{g} / \mathrm{mL})\end{array}$ & $\begin{array}{l}\text { AgNps doses showed few } \\
\text { effects on cell proliferation } \\
\text { below } 10 \mu \text {, while doses above } \\
10 \mu \mathrm{g} \text { resulted in increased } \\
\text { cytotoxicity }\end{array}$ & 48 \\
\hline $\begin{array}{l}\text { Green Synthesis } \\
\text { Indigofera tinctoria leaf } \\
\text { extract }\end{array}$ & Lung cancer & A549 & $\mathrm{IC}_{50}: 56.62 \pm 0.86 \mu \mathrm{g} / \mathrm{ml}$ & $\begin{array}{l}\text { Nanoparticles has higher } \\
\text { antioxidant activities and more } \\
\text { cytotoxic effect on cancer cell } \\
\text { than the pure leaf extract }\end{array}$ & 49 \\
\hline $\begin{array}{l}\text { Green Synthesis } \\
\text { Chaenomeles sinensis }\end{array}$ & $\begin{array}{l}\text { Human breast } \\
\text { cancer }\end{array}$ & MCF7 & $\mathrm{IC}_{50}: 725.93 \mu \mathrm{g} / \mathrm{mL}$ & $\begin{array}{l}\text { Cytotoxic against breast cancer } \\
\text { cells }\end{array}$ & 50 \\
\hline $\begin{array}{l}\text { Green Synthesis } \\
\text { Clinacanthus Nutans }\end{array}$ & $\begin{array}{l}\text { Oral squamous } \\
\text { cell carcinoma }\end{array}$ & HSC-4 & $\mathrm{IC}_{50}: 1.61 \mu \mathrm{g} / \mathrm{mL}$ & $\begin{array}{l}\text { Apoptotic effects observed at } \\
\text { G1 phase and } \mathrm{IC}_{50} \text { was low } \\
\text { compared to few studies }\end{array}$ & 51 \\
\hline
\end{tabular}


comparing potential therapeutic approaches of AgNPs on different cancer types. Currently, the production of many toxicological data related to nanoparticles occasionally causes an adverse perception of their use. Nevertheless, toxicity may be helpful in cancer treatments because the cytotoxic effect is desirable for cancer cells. Many studies suggest that positive results have been obtained when incorporating silver nanoparticles into cancer therapies.

Today, silver nanoparticles, which are present in metallic nanoparticle groups and exhibit antibacterial properties, are frequently used in food shelf life extension, food packaging, medical, biomedical and cosmetic industries. Other biomedical nanomaterials have different biological, physical and chemical properties of silver particles. therefore, silver particles can serve as a therapeutic agent in many biomedical fields.

New properties of silver nanoparticles and rapidly changing new application fields are emerging along with the increase in the number of scientific studies. In particular, the development of different techniques for the synthesis of silver nanoparticles leads to enlarge the application fields in medicine. It is thought that silver nanoparticles produced by green biosynthesis using plant extracts or microorganisms may be more suited to clinical approaches than the physical or chemical methods. Additionally, green biosynthesis of AgNPs is a simple, safe, cost effective and eco friendly approach. Because of all these reasons, green silver nanoparticles seems to be a promising an anti-cancer agent in the field of medicine. But, further researches need to enhance its selectivity on cancer cells, and to determine biocompatibility and side effect in animal models.

\section{References}

1. Albrecht MA, Evan CW, Raston CR. Green chemistry and the health implications of nanoparticles. Green Chem 2006; 8: 417-432.

2. Osuwa JC, Anusionwu PC. Some advances and prospects in nanotechnology: a review. Asian J Inf Technol 2011; 10: 96-100.

3. Sriram MI, Kalishwaralal K, Barathmanikanth S, Gurunathani S. Size-based cytotoxicity of silver nanoparticles in bovine retinal endothelial cells. Nanosci Methods 2012; 1: 56-77.

4. He Y, Li X, Wang J, et al Synthesis, characterization and evaluation cytotoxic activity of silver nanoparticles synthesized by Chinese herbal Cornus officinalis via environment friendly approach. Environ Toxicol Pharmacol 2017; 56: 56-60.
5. Zhu B, Li Y, Lin Z, et al. Silver Nanoparticles Induce hepg-2 Cells Apoptosis Through ROSMediated Signaling pathways. Nanoscale Res Lett 2016; 11: 198.

6. Malik MA, O’Brien P, Revaprasadu N. A simple route to the synthesis of core/shell nanoparticles of chalcogenides. Chemistry of Materials 2002; 14: 2004-2010.

7. Thakkar KN, Mhatre SS, Parikh RY. Biological synthesis of metallic nanoparticles. Nanomedicinee 2010; 6: 257-262.

8. Parikh RY, Singh S, Prasad BLV, Patole MS, Sastry M, Schouche YS. Extracellular synthesis of crystalline silver nanoparticles and molecular evidence of silver resistance from Morganella sp.: towards understanding biochemical synthesis mechanism. ChemBioChem 2008; 9: 1415-1422.

9. Pugazhenthiran N, Anandan S, Kathiravan G, Prakash NKU, Crawford S, Ashokkumar M. Microbial synthesis of silver nanoparticles by Bacillus sp. Journal of Nanoparticle Research 2009; 11: 1811-1815.

10. Gurunathan S, Kalishwaralal K, Vaidyanathan $\mathrm{R}$, et al. Biosynthesis, purification and characterization of silver nanoparticles using Escherichia coli. Colloids and Surf B Biointerfaces 2009; 74: 328-335.

11. Loo CY, Rohanizadeh R, Young PM, et al. Combination of Silver Nanoparticles and Curcumin Nanoparticles for Enhanced Antibiofilm Activities. J Agric Food Chem 2016; 64: 2513-2522.

12. Moyer CA, Brentano L, Gravens D, Margraf HW, Monafo WW. Treatment of large human burns with $0.5 \%$ silver nitrate solution. Arch Surg 1965; 90: 812-867.

13. Silver S. Bacterial silver resistance: molecular biology and uses and misuses of silver compounds. FEMS Microbiol Rev 2003; 27: 341-353.

14. Silver S, Phung LT, Silver G. Silver as biocides in burn and wound dressings and bacterial resistance to silver compounds. J Ind Microbiol Biotechnol 2006; 33: 627-634.

15. Klasen HJ. Historical review of the use of silver in the treatment of burns. I. Early uses. Burns 2000a; 26: 117-130.

16. Klasen HJ. A historical review of the use of silver in the treatment of burns. II. Renewed interest for silver. Burns 2000b; 26: 131-138.

17. Wei L, Lu J, Xu H, Patel A, Chen ZS, Chen G. Silver nanoparticles: synthesis, properties, and therapeutic applications. Drug Discov Today. 2015; 20: 595-601.

18. Raghunandan D, Ravishankar B, Sharanbasava $G$, et al. Anti-cancer studies of noble metal nanoparticles synthesized using different plant extracts. Cancer Nanotechnol 2011; 2: 57-65.

East J Med Volume24, Number:1, January-March/2019 
19. Asharani PV, Hande MP, Valiyaveettil S. Antiproliferative activity of silver nanoparticles. BMC Cell Biology 2009; 10: 65.

20. Greulich C, Diendorf J, Simon T, Eggeler G, Epple M. Uptake and intracellular distribution of silver nanoparticles in human mesenchymal stem cells. Acta Biomaterialia 2011; 7: 347 354.

21. Kim S, Choi JE, Choi J, et al. Oxidative stressdependent toxicity of silver nanoparticles in human hepatoma cells. Toxicology in Vitro 2009; 23: 1076-1084.

22. Héctor RH, Salma JB, Pedro PMC, et al. Effects of $45-\mathrm{nm}$ silver nanoparticles on coronary endothelial cells and isolated rat aortic rings. Toxicology Lett 2009; 191: $305-$ 313.

23. Hsin YH, Chen CF, Huang S, Shih TS, Lai PS, Chueh PJ. The apoptotic effect of nanosilver is mediated by a ROS- and JNK dependent mechanism involving the mitochondrial pathway in NIH3T3 cells. Toxicology Lett 2008; 179: 130-139.

24. Sanpui P, Chattopadhyay A, Ghosh SS. Induction of apoptosis in cancer cells at low silver nanoparticle concentrations using chitosan nanocarrier. ACS Appl Mater Interfaces 2011; 3: 218-228.

25. Ahamed M, Karns M, Goodson M, et al. DNA damage response to different surface chemistry of silver nanoparticles in mammalian cells. Toxicology and Applied Pharmacology 2008; 233: 404-410.

26. Sukirtha R, Manasa Priyanka K, Antony JJ, Kamalakkannan S, Balasubramanian P. Cytotoxic effect of Green synthesized silver nanoparticles using Melia azedarach against in vitro HeLa cell lines and lymphoma mice model. Process Biochemistry 2012; 47: 273279.

27. Kalishwaralal K, Banumathi E, Ram KPS, et al. Silver nanoparticles inhibit VEGF induced cell proliferation and migration in bovine retinal endothelial cells. Colloids and Surfaces B: Biointerfaces 2009; 73: 51-57.

28. Sriram MI, Kanth SBM, Kalishwaralal K, Gurunathan S, Antitumor activity of silver nanoparticles in Dalton's lymphoma ascites tumor model. Inter J Nanomedicine 2010; 5: 753-762.

29. Mukherjee S, Chowdhury D, Kotcherlakota R, et al. Potential theranostics application of biosynthesized silver nanoparticles (4-in-1 system). Theranostics. 2014; 4: 316-335.

30. Ovais M, Khalil AT, Raza A, et al. Multifunctional theranostic applications of biocompatible green-synthesized colloidal nanoparticles. Appl Microbiol Biotechnol. 2018 Mar 29
31. Ovais M, Raza A, Naz S, et al. Current state and prospects of the phytosynthesized colloidal gold nanoparticles and their applications in cancer theranostics. Appl Microbiol Biotechnol 2017; 101: 3551-3565.

32. Mandal RP, Mandal G, Sarkar S, Bhattacharyya A, De S. "Theranostic" role of bile salt-capped silver nanoparticles - gall stone/pigment stone disruption and anticancer activity. J Photochem Photobiol B. 2017; 175: 269-281.

33. Gurunathan S, Raman J, Malek SNA, John PA, Vikineswary S. Green synthesis of silver nanoparticles using Ganoderma neojaponicum Imazeki: a potential cytotoxic agent against breast cancer cells. Int J Nanomedicine 2013; 8: 4399-4413.

34. Nazir S, Hussain T, Iqbal Md, Mazhar K, Muazzam AG, Ismail J Md. Novel and costeffective green synthesis of silver nanoparticles and their in vivo antitumor properties against humancancer cell lines. Biosci Tech 2011; 2: 425-443.

35. Guo D, Zhu L, Huang Z, et al. Anti-leukemia activity of PVP-coated silver nanoparticles via generation of reactive oxygen species and release of silver ions. Biomaterials 2013; 34: 7884-7894.

36. Saratale RG, Benelli G, Kumar G, Kim DS, Saratale GD. Biofabrication of silver nanoparticles using the leaf extract of an ancient herbal medicine, dandelion (Taraxacum officinale), evaluation of their antioxidant, anticancer potential, and antimicrobial activity against phytopathogens. Environ Sci Pollut Res 2018; 25: $10392-$ 10406

37. Kuppusamy P, Ichwan SJ, Al-Zikri PN, et al. In Vitro Anticancer Activity of $\mathrm{Au}, \mathrm{Ag}$ Nanoparticles Synthesized Using Commelina nudiflora L. Aqueous Extract Against HCT116 Colon Cancer Cells. Biol Trace Elem Res 2016; 173: 297-305

38. El-Naggar NE, Hussein MH, El-Sawah AA. Bio-fabrication of silver nanoparticles by phycocyanin, characterization, in vitro anticancer activity against breast cancer cell line and in vivo cytotoxicity. Sci Rep 2017; 7: 10844.

39. Kathiravan V, Ravi S, Ashokkumar S. Synthesis of silver nanoparticles from Melia dubia leaf extract and their in vitro anticancer activity. Spectrochim Acta A Mol Biomol Spectrosc 2014; 130: 116-121.

40. Nagajyothi PC, Sreekanth TVM, Lee JI, Lee KD. Mycosynthesis: antibacterial, antioxidant and antiproliferative activities of silver nanoparticles synthesized from Inonotus obliquus (Chaga mushroom) extract. J

East J Med Volume24, Number:1, January-March/2019 
Photochem Photobiol B Biol 2014; 130: 299304.

41. Rathi Sre PR, Reka M, Poovazhagi R, Arul Kumar M, Murugesan K. Antibacterial and cytotoxic effect of biologically synthesized silver nanoparticles using aqueous root extract of Erythrina indica lam. Spectrochim Acta Part A Mol Biomol Spectrosc 2015; 135: 1137 1144.

42. Krishnaraj C, Muthukumaran P, Ramachandran R, Balakumaran MD, Kalaichelvan PT. Acalypha indica Linn: biogenic synthesis of silver and gold nanoparticles and their cytotoxic effects against MDA-MB-231, human breast cancer cells. Biotechnol Rep 2014; 4: 42-49.

43. Sathishkumar G, Gobinath C, Wilson A, Sivaramakrishnan S. Dendrophthoe falcata (L.f) Ettingsh (Neem mistletoe): a potent bioresource to fabricate silver nanoparticles for anticancer effect against human breast cancer cells (MCF7). Spectrochim Acta Part A Mol Biomol Spectrosc 2014; 128: 285-290.

44. Gajendran B, Chinnasamy A, Durai P, Raman J, Ramar M. Biosynthesis and characterization of silver nanoparticles from Datura inoxia and its apoptotic effect on human breast cancer cell line MCF7. Mater Lett 2014; 122: 98-102.

45. Jacob SJP, Finub JS, NarayananA. Synthesis of silver nanoparticles using Piper longum leaf extracts and its cytotoxic activity against Hep2 cell line. Colloids Surf B Biointerfaces 2012; 91: $212-214$
46. Govindaraju K, Krishnamoorthy K, Alsagaby SA, Singaravelu G, Premanathan M. Green synthesis of silver nanoparticles for selective toxicity towards cancer cells. IET Nanobiotechnol 2015; 9: 325-330.

47. Kaler A, Jain S, Banerjee UC. Green and rapid synthesis of anticancerous silver nanoparticles by Saccharomyces boulardii and insight into mechanism of nanoparticle synthesis. Biomed Res Int 2013; 2013: 872-940.

48. Alsalhi MS, Devanesan S, Alfuraydi AA, et al.. Green synthesis of silver nanoparticles using Pimpinella anisum seeds: antimicrobial activity and cytotoxicity on human neonatal skin stromal cells and colon cancer cells. Int J Nanomedicine 2016; 11: 4439-4449.

49. Vijayan R, Joseph S, Mathew B. Indigofera tinctoria leaf extract mediated green synthesis of silver and gold nanoparticles and assessment of their anticancer, antimicrobial, antioxidant and catalytic properties. Artif Cells Nanomed Biotechnol 2018; 46: 861-871.

50. Oh KH, Soshnikova V, Markus J, et al.. Biosynthesized gold and silver nanoparticles by aqueous fruit extract of Chaenomeles sinensis and screening of their biomedical activities. Artif Cells Nanomed Biotechnol 2018; 46: 599-606.

51. Yakop F, Abd Ghafar SA, Yong YK, et al. Silver nanoparticles Clinacanthus Nutans leaves extract induced apoptosis towards oral squamous cell carcinoma cell lines. Artif Cells Nanomed Biotechnol 2018; 1-9. 